\title{
Kedudukan Pelaku Usaha dan Konsumen Dalam Hukum Perlindungan Konsumen (Kajian Terhadap Produk Mi Soun Mengandung Klorin)
}

\author{
Heru Saputra Lumban Gaol \\ Fransisca Yanita Prawitasari
}

\begin{abstract}
Fakultas Hukum Universitas Surabaya, herusaputra@staff.ubaya.ac.id
Fakultas Hukum Universitas Surabaya, fransisca_yanita@staff.ubaya.ac.id
\end{abstract}

\begin{abstract}
Food is one of the primary needs of humans. In terms of producing food, it cannot be completely separated from the use of Food Additives. Article 1 paragraph (1) of Law Number 033 Year 2012 concerning Food Additives determine Food Additives are ingredients added to food to affect the nature or form of food. This indicates that Food Additives may affect the quality of the product. In practice, not all Food Additives are used by sellers safe for consumers' health. In fact, Article 4 letter a of Law Number 8 of 1999 concerning Consumer Law determines that consumers have the right to conveniences, security and safety in consuming goods and/or services. This is also in line with the seller's obligations that specified in Article 7 of the Consumer Law. A several cases of chlorine additives on mi soun at Klaten, Jember, and Jambi show a lack of awareness of sellers and consumers in recognizing which food additives are harmful for health. Consumer law as a progressive law strives to be a legal means that establish consumer awareness and sellers awareness in order to realize their rights and obligations. Progressive consumer law also indicates a balance between sellers and consumers in harmonizing the principles of caveat venditor and caveat emptor.

keywords: Food Additivies, Consumer Law, Caveat Venditor and Caveat Emptor
\end{abstract}

\section{Pendahuluan}

Pangan merupakan salah satu kebutuhan primer bagi masyarakat dalam rangka mempertahankan kelangsungan hidup. Undang-Undang Nomor 18 Tahun 2012 Tentang Pangan (selanjutnya disebut Undang-Undang Pangan) mendefinisikan secara jelas dan tegas pengertian dari pangan. Pasal 1 angka (1) Undang-Undang Pangan menentukan:

Pangan adalah segala sesuatu yang berasal dari sumber hayati produk pertanian, perkebunan, kehutanan, perikanan, peternakan, perairan, dan air, baik yang diolah maupun tidak diolah yang diperuntukkan sebagai makanan atau minuman bagi konsumsi manusia, termasuk bahan tambahan Pangan, bahan baku Pangan, dan bahan lainnya yang digunakan dalam proses penyiapan, pengolahan, dan/atau pembuatan makanan atau minuman.

Mencermati ketentuan Pasal 1 angka (1) Undang-Undang Pangan ini, maka dapat diketahui unsur-unsur yang melekat pada pengertian pangan meliputi bahan tambahan pangan, bahan baku pangan, dan bahan lainnya dalam proses penyiapan, pengolahan, atau pembuatan makanan dan minuman yang dikonsumsi oleh manusia.

Tidak dapat dipungkiri dalam proses pengolahan atau pembuatan pangan selain membutuhkan bahan baku pangan sebagai komponen utama, dalam praktiknya membutuhkan komponen bahan tambahan lain. Bahan tambahan dalam suatu produk lazim disebut sebagai Bahan Tambahan Pangan. Pasal 1 angka (1) Peraturan Menteri Kesehatan Nomor 033 Tahun 2012 tentang Bahan Tambahan Pangan (selanjutnya disebut Permenkes Bahan Tambahan Pangan)

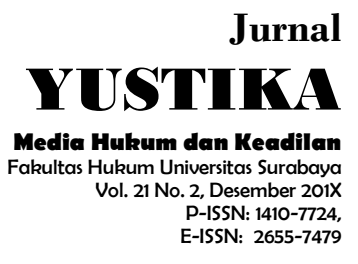


Jurnal Yustika

Vol. 21 No. 2, Des 2018

Halaman I 29

Kedudukan Pelaku

Usaha dan

Konsumen dalam

Hukum

Perlindungan

Konsumen

Heru S. Lumban Gaol

Fransisca Y. Prawitasari menentukan: "Bahan Tambahan Pangan yang selanjutnya disingkat BTP adalah bahan yang ditambahkan ke dalam pangan untuk mempengaruhi sifat atau bentuk pangan".

Masyarakat pada umumnya cenderung mengkonsumsi produk makanan dan minuman tanpa memperhatikan kandungan BTP yang tertera pada label kemasan. Persoalan lain adalah tidak semua produk makanan dan minuman yang diproduksi oleh pelaku usaha menyertakan label pada kemasan yang mecantumkan unsur BTP dalam produknya, khusunya pelaku usaha dalam skala kecil atau pelaku usaha perorangan. Padahal dalam keberadaan label komposisi bahan baku dan BTP dalam produk makanan dan minuman merupakan hak konsumen sebagaimana yang ditentukan dalam Undang-Undang Nomor 8 tahun 1999 tentang Perlindungan Konsumen (selanjutkan disebut Undang-Undang Perlindungan Konsumen). Pasal 4 huruf a dan c Undang-Undang Perlindungan Konsumen menentukan hak konsumen adalah:

a. hak atas kenyamanan, keamanan, dan keselamatan dalam mengkonsumsi barang dan/atau jasa;

c. hak atas informasi yang benar, jelas, dan jujur mengenai kondisi dan jaminan barang dan/atau jasa.

Keberadaan informasi, baik itu bahan baku dan BTP dalam produk makanan dan minuman adalah dalam rangka memenuhi ketentuan Pasal 4 huruf a dan c tersebut. Ketersediaan informasi yang jelas pada produk barang/jasa, sekaligus membantu konsumen dalam menentukan pilihan untuk membeli barang/jasa.

Ketentuan Pasal 4 huruf a dan c ini juga berbarengan dengan kewajiban pelaku usaha sebagaimana ditentukan dalam Pasal 7 huruf b Undang-Undang Perlindungan Konsumen Pelaku usaha wajib untuk memberikan "informasi yang benar, jelas, dan jujur mengenai kondisi dan jaminan barang dan/atau jasa serta memberikan penjelasan penggunaan, pemakaian, dan pemeliharaan". Kesinambungan antara hak konsumen dan kewajiban pelaku usaha yang ditentukan secara jelas dalam Undang-Undang Perlindungan Konsumen ini sekaligus mendudukan keduanya dalam hubungan hukum yang saling melengkapi.

Realitanya, persoalan BTP dalam pengolahan bahan baku pangan sering dipandang sebelah mata oleh pelaku usaha, pemerintah, dan masyarakat sendiri sebagai konsumen (Ali Khomsan, 2006). Hal ini disebabkan tingkat pengetahuan dan pemahaman masyarakat sebagai konsumen terhadap persoalan makanan dan minuman sangat kurang. Padahal, makanan dan minuman yang dikonsumsi menentukan kualitas hidup masyarakat itu sendiri. Perilaku pelaku usaha mengabaikan keberadaan bahan baku pangan, BTP, dan bahan lainnya dalam proses penyiapan, pengolahan, atau pembuatan makanan dan minuman juga berkaitan erat dengan efisensi modal usaha dan sebagai upaya instan dalam mengolah bahan baku pangan menjadi produk yang siap untuk dipasarkan.

Kurangnya kesadaran konsumen dan pelaku usaha dalam pengolahan pangan yang berkualitas dan bergizi, secara tidak langsung dapat membawa dampak buruk bagi kesehatan konsumen. Terlebih, faktanya banyak produk makanan dan minuman yang jelas mengandung BTP kimiawi. Dampak atau efek samping dari produk makanan dan minuman tersebut mungkin tidak akan langsung dirasakan setelah mengkonsumsi produk makanan dan minuman tersebut, namun membutuhkan waktu lama sampai bahan-bahan kimia Apabila tersebut akhirnya larut dan mengendap di dalam tubuh. Persoalan BTP kimiawi semakin menjadi perhatian yang penting apabila produk pangan tersebut juga dikonsumsi secara berkala. Bahkan, produk tersebut dapat saja menjadi panganan utama atau sumber kabohidrat utama pengganti nasi, seperti halnya pada produk mi soun. 
Beberapa kasus mencatat produk mi soun yang terbuat dari pati aren sebagai bahan baku utama dalam proses pengolahannya diinjak menggunakan telapak kaki yang kurang hiegenis. Kemudian, proses pemisahan antara kotoran dan sari pati aren yang sudah berbentuk serat benang tidak hanya dibilas menggunakan air, tetapi juga menggunakan campuran klorin atau biasa disebut kaporit. Penggunaan klorin bertujuan agar mengubah warna kecoklatan serabut benang sari pati menjadi berwarna putih. Kasus ini terjadi di Desa Daleman, Kecamatan Tulung, Kabupaten Klaten, Jawa Tengah (liputan6.com). Kasus lainnya terjadi pada bulan Juni 2017 di Desa Rowo Tengah, Kecamatan Ajung, Jember, Jawa Timur, dimana salah satu pabrik yang telah beroperasi sejak tahun 2008 menggunakan bahan kimia klorin untuk membuat mi soun menjadi lebih putih (liputan6.com). Lalu, kasus serupa juga terjadi di Desa Kasang Pudak, Kabupaten Muaro, Jambi pada bulan Juli 2017 (http://jambi.antaranews.com). Beberapa kasus yang terjadi ini menunjukan kurangnya kesadaran pelaku usaha atas bahaya BTP yang mengandung kaporit bagi kesehatan konsumen.

Persoalan BTP berupa senyawa klorin pada mi soun muncul akibat ketidaktahuan masyarakat dan pelaku usaha atas dampak dan bahaya klorin sebagai BTP. Beberapa asumsi muncul mengingat masyarakat berasumsi penggunaan kaporit atau klorin sebagai zat pelarut bakteri di kolam renang dinilai aman digunakan selama ini. Sehingga, tindakan merendam produk makanan (mi soun) dalam klorin dianalogikan juga tidak berdampak signifikan pada kesehatan konsumen. Asumsi ini diperkuat pula dengan dalih pelaku usaha yang menyatakan bahwa, produk mi soun yang telah direndam ke dalam klorin selanjutnya akan dibilas kembali menggunakan air bersih. Hal demikian dianggap mampu mengurangi kandungan klorin dalam produk mi soun (Fransisca Yanita Prawitasari, 2013).

Ketidakjelasan senyawa klorin sebagai bahan tambahan pangan ini sendiri bahkan menjadi perdebatan hingga saat ini. Di beberapa Negara seperti di Amerika dan Eropa memang penggunaan klorin sebagai BTP diperkenankan. "Penggunaan klorin sebagai BTP diatur dalam peraturan FDA 21 CFR 137.105, dengan jumlah penggunaan klorin tidak melebihi 45 ppm dan di Eropa klorin sebagai BTP dengan nomor E (E number) 925 yang berfungsi sebagai anti mikroba, anti kapang, pemutih, pematang, dan pengoksidasi"(C. Hanny Wijaya, 2007). Larangan klorin sendiri sebagai BTP secara implisit tidak tercantum dalam Lampiran II Permenkes Bahan Tambahan Pangan. Namun dalam beberapa literasi dan penelitian, klorin diakui dapat berdampak negatif terhadap kesehatan manusia. Sehingga, sebenarnya baik itu pelaku usaha dan konsumen dapat melakukan upaya terlebih dahulu untuk mencari informasi terkait dampak penggunaan klorin dalam pangan.

Berkaitan dengan hal tersebut, perkembangan teknologi dan terbukanya era globalisasi secara tidak langsung membuka perspektif baru mengenai konsep hukum perlindungan konsumen. Hal ini sekaligus memberikan kesempatan bagi konsumen untuk dapat menyadari bahwa kepentingannya dilindungi oleh negara. Konsumen dinilai semakin kritis, sehingga konsep pasar yang sebelumnya ada dalam tatanan lama, dimana pelaku usaha berada dalam posisi yang lebih kuat kini berubah dalam perspektif baru. Komunitas pelaku usaha dituntut untuk mengubah paradigmanya yang pada awalnya let buyer be aware menjadi let seller be aware (Zulham, 2013). Selain itu, dengan hadirnya Undang-Undang Perlindungan Konsumen sebagai embrio politik hukum bisnis, maka secara langsung melindungi kepentingan konsumen itu sendiri sebagai pengguna barang dan/atau jasa dalam sektor ekonomi dari eksploitasi pelaku usaha. Konsumen kemudian diberikan atribut secara normatif untuk menuntut hak-haknya (Firman Tumantara Endipradja, 2016). Konsekuensi hukum yang muncul dari perlindungan 
Jurnal Yustika

Vol. 21 No. 2, Des 2018

Halaman | 31

Kedudukan Pelaku

Usaha dan

Konsumen dalam

Hukum

Perlindungan

Konsumen

Heru S. Lumban Gaol

Fransisca Y. Prawitasari konsumen adalah pelaku usaha harus memperhatikan segala aspek dalam kegiatan produksinya, termasuk dalam pengolahan bahan baku dan penggunaan BTP yang aman untuk dikonsumsi konsumen.

Melihat uraian yang telah dikemukan sebelumnya yang menjadi pokok persoalannya adalah timbul ketidakjelasan atau kerancuan apabila penggunaan BTP dalam produk mi soun tidak ditentukan secara implisit dan tegas dalam ketentuan perundang-undangan. Terlebih di beberapa Negara, praktik penggunaan klorin diperkenankan sebagai BTP. Keadaan ini semakin diperburuk dengan lemahnya kesadaran hukum konsumen untuk memperhatikan pentingnya aksesibilitas informasi atas pangan yang akan dikonsumsinya. Hal ini menyebabkan kedudukan konsumen kembali pada titik terendah dalam Hukum Perlindungan Konsumen dan tentu tidak sejalan dengan konsep hukum progresif. Konsep hukum progresif menuntut kesadaran baik itu pelaku usaha dan konsumen untuk memahami hak dan kewajibannya sebagai subyek hukum dalam Hukum Perlindungan Konsumen. Kondisi ini juga tidak sejalan dengan salah satu tujuan politik Hukum Perlindungan Konsumen yang ditentukan dalam Pasal 3 Undang-Undang Perlindungan Konsumen, yaitu meningkatkan kesadaran, kemampuan, dan kemandirian konsumen untuk melindungi diri.

\section{Pembahasan}

\subsection{Bahan Tambahan Pangan (BTP) dan Senyawa Klorin Dalam Produk Mi Soun}

Pasal 1 angka (1) Permen BTP menentukan BTP adalah bahan yang ditambahkan ke dalam pangan untuk mempengaruhi sifat atau bentuk pangan. BTP bukan merupakan bahan baku pangan dan tidak dikonsumsi langsung oleh konsumen. Penggunaan BTP ditujukan untuk mengubah sifat-sifat makanan, seperti bentuk, tekstur, warna, rasa, aroma, dan mengawetkan makanan dan minuman (Elly Hernawati, 2017). Penggunaan BTP dalam kehidupan sehari-hari juga bertujuan menghemat biaya dalam proses pengolahan bahan baku makanan dan minuman (Yuliarti, 2007). Dalam praktiknya, pelaku usaha dalam mengolah suatu bahan baku pangan sangat sulit lepas dari kebutuhan akan BTP.

Garis besar mengenai bahan tambahan dalam pangan dapat diklasifikasikan dalam dua kelompok, yaitu bahan tambahan yang diperkenankan dalam pangan dengan nilai ambang batas tertentu dan bahan yang dilarang digunakan sebagai bahan tambahan dalam produk makanan dan minuman. Mengenai hal ini ditentukan dalam Pasal 75 ayat (1) huruf a dan b UndangUndang Nomor 18 Tahun 2012 tentang Pangan (selanjutnya disebut Undang-Undang Pangan). Ratio legis BTP diperkenankan dalam pengolahan makanan dan minuman merujuk pada Bagian Penjelasan Pasal 75 ayat (1) huruf a Undang-Undang Pangan. "Penggunaan BTP dalam produk Pangan diperkenankan apabila bahan tambahan tersebut tidak mempunyai resiko terhadap kesehatan manusia karena lazim digunakan. Namun penggunaannya tidak diperkenankan melampaui ambang batas maksimal". Penggunaan BTP pada dasarnya juga membawa dampak meningkatkan kualitas pangan serta dapat mencegah pertumbuhan mikroba yang dapat merusak pangan dan menurunkan mutu pangan (Yuliarti, 2007). Hal ini menunjukan bahwa BTP sebagai pelengkap bahan baku Pangan tidak selalu berkonotasi negatif.

Perkenaan BTP yang digunakan dalam produksi makanan dan minuman ditentukan dalam Pasal 2 huruf a, b, dan c Permenkes Bahan Tambahan Pangan. Persyaratan yang harus dipenuhi adalah sebagai berikut:

a. BTP tidak dimaksudkan untuk dikonsumsi secara langsung dan/atau tidak diperlakukan sebagai bahan baku pangan. 
b. BTP dapat mempunyai atau tidak mempunyai nilai gizi, yang sengaja ditambahkan ke dalam pangan untuk tujuan teknologis pada pembuatan, pengolahan, perlakuan, pengepakan, pengemasan, penyimpanan dan/atau pengangkutan pangan untuk menghasilkan atau diharapkan menghasilkan suatu komponen atau mempengaruhi sifat pangan tersebut, baik secara langsung atau tidak langsung.

c. BTP tidak termasuk cemaran atau bahan yang ditambvahkan ke dalam pangan untuk mempertahankan atau meningkatkan nilai gizi.

Jenis BTP juga dikategorikan menjadi GRAS (General Recognized as Safe),zat ini aman dan tidak berefek toksik bagi tubuh, misalnya gula (glukosa). Selain itu, jenis kedua adalah ADI (Acaptable Daily Intake), jenis ini ditetapkan batas penggunaan hariannya (daily intake) demi melindungi kesehatan konsumen (Usay Al-Shirrazy, 2014).

Senyawa klorin merupakan bahan kimia berwujud gas berwarna kuning kehijauan dan memiliki bau cukup menyengat (Dewi Rosita,dkk, 2016). Dalam kehidupan sehari-hari klorin dapat digunakan sebagai pembunuh kuman, seperti halnya pada penggunaan klorin di kolam renang. Pada praktiknya, penggunaan klorin juga digunakan dalam industri makanan, yakni pada produk beras, tepung, dan mi soun. Penggunaan klorin sebagai BTP ini telah diatur oleh beberapa Negara penggunaannya sesuai dengan ambang batas tertentu. "Penggunaan klorin sebagai BTP di Negara Amerika diatur dalam peraturan FDA (Food, and Drug Administratiton) 21 CFR 137.105, dengan jumlah penggunaan klorin tidak melebihi 45 ppm. Di Eropa klorin dikenal sebagai BTP dengan nomor E (E number) 925 yang berfungsi sebagai anti mikroba, anti kapang, pemutih, pematang, dan pengoksidasi"(C. Hanny Wijaya, 2007). Di Indonesia mengenai pengaturan mengenai klorin tidak secara tegas dimasukan sebagai BTP yang dilarang. Dalam Permenkes Bahan Tambahan Pangan hanya ditentukan klorin bukan termasuk ke dalam bahan tambahan pangan yang diizinkan ditambahkan dalam produk makanan dan minuman dengan tujuan apapun. Hal ini kemudian menimbulkan ambiguitas bagi masyarakat awam. "Padahal, penggunaan klorin dalam pangan dapat menimbulkan gangguan baik jangka pendek maupun jangka panjang" (Kemenkes RI, 2012).

Efek yang ditimbulkan oleh penggunaan klorin sebagai BTP juga kurang disadari oleh pelaku usaha, padahal klorin yang secara terus menerus dikonsumsi oleh konsumen dengan kadar melebihi ambang batas berbahaya bagi kesehatan manusia. "Berdasarkan efek yang ditimbulkan oleh klorin tersebut, maka pemerintah tidak memasukkan klorin dalam BTP." (Dewi Rosita,dkk, 2016) Larangan klorin dalam BTP secara implisit tidak tercantum dalam Lampiran II Permenkes Bahan Tambahan Pangan, yang menyatakan demikian:

Bahan yang Dilarang Digunakan sebagai BTP

\begin{tabular}{|l|l|}
\hline No. & Nama Bahan \\
\hline 1. & Asam borat dan senyawanya (Boric acid) \\
\hline 2. & Asam salisilat dan garamnya (salicylic acid and its salt) \\
\hline 3. & Dietilpirokarbonat (Diethylpyrocarbonate, DEPC) \\
\hline 4. & Dulsin (Dulcin) \\
\hline 5. & Formalin (Formaldehyde) \\
\hline 6. & Kalium bromat (Potassium bromate) \\
\hline 7. & Kalium klorat (Potassium chlorate) \\
\hline 8. & Kloramfenikol (Chloramphenicol) \\
\hline 9. & Minyak nabati yang dibrominasi (Brominated vegetable olis) \\
\hline 10. & Nitrofurazon (Nitrofurazone) \\
\hline 11. & Dulkamara (Dulcamara) \\
\hline
\end{tabular}


Jurnal Yustika

Vol. 21 No. 2, Des 2018

Halaman I 33

Kedudukan Pelaku

Usaha dan

Konsumen dalam

Hukum

Perlindungan

Konsumen

Heru S. Lumban Gaol

Fransisca Y. Prawitasari

\begin{tabular}{|l|l|}
\hline 12. & Kokain (Cocaine) \\
\hline 13. & Nitrobenzen (Nitrobenzene) \\
\hline 14. & Sinamil antranilat (Cinnamyl anthranilate) \\
\hline 15. & Dihidrosafrol (Dohydrosafrole) \\
\hline 16. & Biji tonka (Tonka bean) \\
\hline 17. & Minyak kalamus (Calamus oil) \\
\hline 18. & Minyak tansi (Tansy oil) \\
\hline 19. & Minyak sasafras (Sasafras oil) \\
\hline
\end{tabular}

Klorin juga tidak termasuk dalam Lampiran I Permenkes Bahan Tambahan Pangan sebagai kategori BTP yang diizinkan. Meninjau hal tersebut, penggunaan senyawa klorin dapat menimbulkan penafsiran yang ambigu bagi pelaku usaha maupun konsumen, khsusunya yang awam di bidang hukum. Akibatnya, pengunaan klorin sebagai BTP dalam produk mi soun seringkali menjadi pembiaraan, setidaknya karena ketidaktauan masyarakat. Penggunaanya dalam produk pangan bahkan disamakan dengan penggunaan klorin sebagai anti mikroba di kolam renang. Klorin dinilai wajar digunakan dalam proses perendaman mi soun, karena akan dibilas lagi menggunakan air. Hal ini tentu keliru mengingat efek yang dapat ditimbulkan apabila konsumen mengkonsumsi makanan dengan kadar klorin yang berlebihan akan berindikasi pada kesehatan tubuh manusia.

Gejala-gejala keracunan hypochlorite atau kaporit adalah sebagai berikut (A. Adiwisastra, 1987):

a. Rasa sakit terbakar pada rongga mulut, pharynx, esophagus (tenggorokan), lambung, dan erosi pada selaput lendir jaringan-jaringan;

b. Muntah-muntah dan cairan muntah menyerupai kopi, hal ini disebabkan adanya pendarahan pada lambung (haemorrhage);

c. Kolap sirkulasi (circulatory collaps) dengan gejala-gejala kulit dingin dan pucat (clammy and cyanosis), pernapasan menjadi dangkal/dalam (shallow respirations);

d.Konfusi, delirium (mengacau, perubahan rohani mendadak) dan koma (pingsan);

e. Edema dari pharynx dan larynx (busung pangkal tenggorokan dan kerongkongan) dengan stridor (suara mencicit waktu bernapas) dan timbulnya pengerutan (obstruction);

f. Perforasi pada lambung (selaput lambung berlubang/bocor) demikian pula esophagus dengan gejala-gejala mediastinitis dan peritonitis (radang selaput lambung/perut);

g. Menghirup bahan hypochlorite asam menyebabkan iritasi pada selaput lendir saluran pernapasan dan menyebabkan edema paru-paru (pulmonary edema);

h.Kontak dengan kulit (tertumpah ke kulit) menyebabkan gelembung-gelembung yang pecah (vesicoulor eruptions) dan exematoid dermatitis.

Penggunaan klorin dalam produksi pangan, khususnya dalam pengolahan produk mi soun telah menimbulkan kekhawatiran contohnya pada kasus pembuatan mi soun di Desa Daleman, Kabupaten Klaten pada tahun 2012; Desa Rowo Tengah, Kabupaten Jember pada tahun 2017; dan di Desa Lopak Alai, Kabupaten Muaro Jambi pada tahun 2017. Ketiga lokasi tersebut merupakan lokasi penghasil produk mi soun yang pada tahap proses pemisahan antara kotoran dan pati aren menggunakan bilasan air mengandung klorin sebagai pemuttih. Kasus demikian sudah terjadi mulai dari tahun 2012 dan terus berlanjut hingga tahun 2017, bahkan mungkin berlanjut hingga saat ini. Sayangnya, masyarakat sebagai konsumen tidak sadar bahwa produk yang mereka konsumsi berbahaya bagi kesehatan atau konsumen tersebut memang tidak peduli terhadap produk yang mereka konsumsi sehari-hari. 
Ironisnya lagi produk mi soun menjadi salah satu jenis makanan yang banyak dikonsumsi oleh masyarakat Indonesia sebagai pelengkap dalam masakan tertentu. Produksi mi soun di Indonesia, khususnya di pulau Jawa telah menjadi mata pencaharian sebagian masyarakat. Data dari Disperindagkop dan UMKM Kabupaten Klaten menunjukkan, bahwa terdapat 70 UMKM produksi mi soun yang tersebar di wilayah Klaten dengan menghasilkan berton-ton mi soun setiap harinya (Bunga Septiana Belia, 2015). Ini mengindikasikan produksi mi soun telah menjadi kebutuhan baik bagi pelaku usaha dan juga konsumen.

\subsection{Tanggung Jawab Produk Dalam Hukum Perlindungan Konsumen}

Perkembangan ilmu pengetahuan dan teknologi dalam setiap lini kehidupan masyarakat mempengaruhi perilaku pelaku usaha dalam memproduksi atau menghasilkan berbagai macam barang dan jasa. Hal ini kemudian mendorong terciptanya doktrin-doktrin baru dalam kajian hukum perlindungan konsumen, salah satunya adalah bentuk tanggung jawab pelaku usaha terhadap konsumen pada cacat produk yang terjadi (Aulia Muthiah, 2018). Kamus Besar Bahasa Indonesia (KBBI) mendefinisikan tanggung jawab sebagai keadaan wajib menanggung segala sesuatunya atau keadaan menerima pembebanan sebagai akibat sikap pihak sendiri atau pihak lain (https://kbbi.web.id). Dalam hukum perlindungan konsumen yang diadopsi di Indonesia, prinsip tanggung jawab mengikuti perkembangan yang terjadi di negara Amerika dan Eropa, yaitu prinsip tanggung jawab mutlak (strict liability). Hal ini dipengaruhi oleh pergeseran prinsip yang semula menerapkan strategi product oriented dalam pemasaran produknya, menjadi consumer oriented (Andi Sri Rezky Wulandari \& Nurdiyana Tadjuddin, 2018).

Undang-Undang Perlindungan Konsumen mengakomodasi dua prinsip penting tanggung jawab, yaitu tanggung jawab produk (product liability) dan tanggung jawab profesional (professional liability). Tanggung jawab produk merupakan tanggung jawab pelaku usaha atas produk yang dipasarkan kepada konsumen, yang menimbulkan kerugian akibat cacat yang terkandung dalam produk tersebut. Tanggung jawab profesional berhubungan dengan jasa, yakni tanggung jawab produsen terkait dengan jasa profesional yang diberikan pada pengguna jasa (Zulham, 2013). Penerapan prinsip tanggung jawab mutlak (strict liability) didasarkan pada alasan bahwa konsumen tidak dapat berbuat banyak untuk memproteksi diri dari resiko kerugian yang dialaminya. Selain itu, perkembangan sistem pemasaran yang digunakan oleh pelaku usaha akan mempersulit konsumen untuk membuktikan kesalahan pelaku usaha (Aulia Muthiah, 2018). Sederhananya, perkembangannya prinsip tanggung jawab mutlak (strict liability) ini muncul dengan gagasan bahwa pelaku usaha lah yang pertama kali mengetahui kedaan mengenai produk atau jasa yang dihasilkannya.

Berkaitan dengan tanggung jawab produk (product liability), untuk menentukan suatu produk dapat dikatakan sebagai produk cacat dapat dibedakan dalam tiga kemungkinan, yaitu kesalahan dalam proses produksi produk, cacat desain, dan cacat peringatan atau instruksi (Aulia Muthiah, 2018). Emma Suratman (Andi Sri Rezky Wulandari \& Nurdiyana Tadjuddin, 2018) mendefinisikan produk cacat adalah:

setiap produk yang tidak dapat memenuhi tujuan pembuatannya baik karena kesengajaan atau kealpaan dalam proses produksinya maupun disebabkan hal-hal lain yang terjadi dalam peredarannya, atau tidak menyediakan syarat-syarat keamanan bagi manusia atau harta benda dalam penggunaanya, sebagaimana diharapkan orang.

Pengertian ini menegaskan bahwa unsur pertanggung jawaban mutlak yang dikaitkan pada kondisi produk akan menunjuk pada kecacatan yang ada pada produk tersebut, sehingga penekannya pertama kali bukan pada perilaku pelaku usaha. Hal ini lah yang kemudian menjadi 
Jurnal Yustika

Vol. 21 No. 2, Des 2018

Halaman | 35

Kedudukan Pelaku

Usaha dan

Konsumen dalam

Hukum

Perlindungan

Konsumen

Heru S. Lumban Gaol

Fransisca Y. Prawitasari dasar diberlakukannya beban pembuktian terbalik dalam praktik Undang-Undang Perlindungan Konsumen.

Ketentuan mengenai tanggung jawab mutlak (strict liability) terlihat jelas dalam Pasal 19 Undang-Undang Perlindungan Konsumen, yang menentukan:

1.Pelaku usaha bertanggung jawab memberikan ganti rugi atas kerusakan, pencemaran, dan/atau kerugian konsumen akibat mengkonsumsi barang dan/atau jasa yang dihasilkan atau diperdagangkan.

2.Ganti rugi sebagaimana dimaksud pada ayat (1) dapat berupa pengembalian uang atau penggantian barang dan/atau jasa yang sejenis atau setara nilainya, atau perawatan kesehatan dan/atau pemberian santunan yang sesuai dengan ketentuan peraturan perundang-undangan yang berlaku.

3.Pemberian ganti rugi dilaksanakan dalam tenggat waktu tujuh hari setelah tanggal transaksi.

4.Pemberian ganti rugi sebagimana yang dimaksud pada ayat (1) dan ayat (2) tidak menghapuskan kemungkinan adanya tuntutan pidana berdasarkan pembuktian lebih lanjut mengenai adanya unsur kesalahan.

5.Ketentuan sebgaimana dimaksud pada ayat (1) dan ayat (2) tidak berlaku apabila pelaku usaha dapat membuktikan bahwa kesalahan tersebut merupakan kesalahan konsumen.

Prinsip tanggung jawab mutlak (strict liability) dalam hukum perlindungan konsumen ini tidak identik dengan tanggung jawab absolut (absolute liability). Ini berarti ada pengecualianpengecualian tertentu yang dapat membebaskan pelaku usaha dari tanggung jawabnya sebagaimana ditentukan dalam Undang-Undang Perlindungan Konsumen. Pertama, barang tersebut terbukti seharusnya tidak diedarkan atau tidak dimaksudkan untuk diedarkan. Kedua, cacat barang timbul pada kemudian hari. Ketiga, cacat timbul akibat ditaatinya ketentuan mengenai kualifikasi barang (Zulham, 2013). Pada pengecualian pertama hingga ketiga jelas terlihat bahwa pengeculian tanggung jawab didasarkan pada itikad baik yang sudah dilakukan oleh pelaku usaha sebagai kewajibannya dalam Pasal 7 Undang-Undang Perlindungan Konsumen.

Pengecualian tanggung jawab pelaku usaha yang keempat, adalah kelalaian yang diakibatkan oleh konsumen. Kelima, lewatnya jangka waktu penuntutan empat tahun sejak barang dibeli atau lewatnya jangka waktu yang diperjanjikan (Zulham, 2013). Untuk pengecualian yang keempat dan kelima, pembebasan tanggung jawab berfokus pada perilaku konsumen berkaitan dengan pendidikan dan pembinaan konsumen sebagai konsumen yang cerdas. Kelalaian konsumen dalam menggunakan produk seperti tidak mengikuti petunjuk pemakaian, mengkonsumsi produk lewat dari jangka waktu yang dianjurkan, dan sebagainya menyebabkan tanggung jawab itu beralih pada konsumen itu sendiri. Kemudian pengecualian kelima juga menunjuk pada perilaku konsumen dalam hal mengajukan tuntutan kepada pelaku usaha, dimana konsumen hanya diperbolehkan menuntut pelaku usaha dalam kurun waktu empat tahun atau jangka waktu yang diperjanjikan oleh kedua belah pihak. Apabila konsumen semula mengabaikan haknya untuk menuntut, kemudian setelah lewatnya jangka waktu yang ditentukan konsumen tersebut mengubah pikirannya untuk menuntut, maka pelaku usaha tidak dapat dimintakan pertanggungjawaban.

Kedua hal ini sekaligus menjadi kelemahan dalam hal melindungi kepentingan konsumen dan menyebabkan kedudukan konsumen kembali pada titik terendah. Persoalannya tidak semua konsumen menyadari bahwa prinsip kehati-hatian konsumen (let buyer be aware) juga melakat pada konsumen itu sendiri dan menjadi dasar pengecualian atas tanggung jawab produk. 
Kebanyakan konsumen hanya berpikir mengenai haknya, akan tetapi mengabaikan kewajibannya. Selanjutnya, tidak semua konsumen memahami mekanisme dalam mengajukan tuntutan atas kerugian yang dideritanya. Bahkan, perilaku konsumen cenderung masih nir aksi dan ragam aksi. Persoalan lain adalah tidak semua produk mendatangkan dampak atau efek seketika dalam penggunaanya. Beberapa produk yang menggunakan BTP membutuhkan akumulasi waktu tertentu yang dapat menyebabkan dampak bagi kesehatan tubuh. Sehingga, penetapan jangka waktu penuntutan empat tahun sejak barang dibeli atau lewatnya jangka waktu yang diperjanjikan tidak selalu memberikan kepastian hukum bagi konsumen.

\subsection{Kedudukan Pelaku Usaha dan Konsumen dalam Hukum Perlindungan Konsumen}

Secara umum hubungan hukum antara pelaku usaha dan konsumen merupakan hubungan yang berkesinambungan dan lahir dari adanya hukum permintaan dan penawaran dalam pasar. Hubungan hukum tersebut lahir dari kehendak kedua belah pihak dan keduanya saling memiliki ketergantungan satu sama lain (Zulham, 2013). Hubungan hukum konsumen dan pelaku usaha dapat dicermati dari pengertian keduanya dalam ketentuan hukum yang berlaku. Pasal 1 angka (2) Undang-Undang Perlindungan Konsumen menentukan "Konsumen adalah setiap orang pemakai barang dan/atau jasa yang tersedia dalam masyarakat, baik bagi kepentingan diri sendiri, keluarga, orang lain, maupun makhluk hidup lain dan tidak untuk diperdagangkan". Sedangkan Pelaku Usaha adalah mereka yang menyelenggarakan kegiatan usaha dalam berbagai bidang ekonomi sebegaimana ditentukan dalam Pasal 1 angka (3) UndangUndang Perlindungan Konsumen.

Ruang lingkup yang melekat dalam hubungan pelaku udaha dan konsumen sebenarnya dibagi dalam dua dimensi hukum yaitu hukum konsumen dan hukum perlindungan konsumen. Hukum konsumen pada pokoknya lebih berperan dalam hubungan dan masalah konsumen yang kondisi para pihaknya berimbang dalam kedudukan sosial ekonomi, daya saing, dan tingkat pendidikan. Sementara, hukum perlindungan konsumen merupakan genus dari hukum konsumen yang mengatur dan melindungi kepentingan konsumen (Firman Tumantara Endipradja, 2016). Hukum perlindungan konsumen dapat juga didefinisikan sebagai keseluruhan peraturan perundang-undangan serta putusan hakim yang secara substansi mengatur kepentingan konsumen (Inosentius Samsul, 2004).

Hukum perlindungan konsumen lahir dari adanya keasadaran konsumen bahwa adanya hubungan hukum yang tidak seimbang antara pelaku usaha dan konsumen. Secara sosiologis, hukum perlindungan konsumen hadir untuk memberi kepastian hukum yang melindungi kepentingan konsumen. Hal ini mengingat konsumen seringkali ada dalam posisi pihak lebih lemah dari pelaku usaha (Firman Tumantara Endipradja, 2016). Konsep hukum perlindungan konsumen juga lahir dari gerakan perlindungan konsumen yang menjunjung tinggi perlindungan hak-hak konsumen dalam hubungan horizontal antara masyarakat dan pelaku usaha yang tidak lepas dari praktik eksplotasi (Inosentius Samsul, 2004).

Kebijakan hukum dan politik hukum perlindungan konsumen ini secara tidak langsung juga membawa konsekuensi hukum bagi konsumen dan pelaku usaha, khsusunya terkait hak dan kewajiban sebagai subyek hukum perlindungan konsumen. John F. Kennedy membagi hak konsumen secara universal dalam empat hal, yaitu hak atas keamaan dan keselamatan (the right to safety), hak atas informasi (the right to be informed), hak untuk memilih (the right to choose), hak untuk didengar (the right to be heard) (Aulia Muthiah, 2018). Keempat hak ini berkembang dengan dimasukannya hak mendapatkan pendidikan konsumen, hak atas ganti rugi, dan hak atas lingkungan hidup (Andi Sri Rezky Wulandri \& Nurdiyana Tadjuddin, 2018). Dalam Undang- 
Jurnal Yustika

Vol. 21 No. 2, Des 2018

Halaman | 37

Kedudukan Pelaku

Usaha dan

Konsumen dalam

Hukum

Perlindungan

Konsumen

Heru S. Lumban Gaol

Fransisca Y. Prawitasari
Undang Perlindungan Konsumen terkait hak konsumen ini dijabarkan lagi dalam point-point yang lebih luas.

Undang-Undang Perlindungan Konsumen menentukan hak konsumen dalam Pasal 4 meliputi:

a. hak atas kenyamanan, keamanan dan keselamatan dalam mengkonsurnsi barang dan/atau jasa;

b. hak untuk memilih barang dan/atau jasa serta mendapatkan barang dan/atau jasa tersebut sesuai dengan nilai tukar dan kondisi serta jaminan yang dijanjikan;

c. hak atas informasi yang benar, jelas, dan jujur mengenai kondisi dan jaminan barang dan/atau jasa;

d. hak untuk didengar pendapat dan keluhannya atas barang dan/atau jasa yang digunakan;

e. hak untuk mendapatkan advokasi, perlindungan, dan upaya penyelesaian sengketa perlindungan konsumen secara patut;

f. hak untuk mendapat pembinaan dan pendidikan konsumen;

g. hak untuk diperlakukan atau dilayani secara benar dan jujur serta tidak diskriminatif;

h. hak untuk mendapatkan komnpensasi, ganti rugi dan/atau penggantian, apabila barang dan/atau jasa yang diterima tidak sesuai dengan perjanjian atau tidak sebagaimana mestinya;

i. hak-hak yang diatur dalam ketentuan peraturan perundang-undangan lainnya.

Adapun hak konsumen ini berjalan berdampingan dengan kewajiban konsumen sebagaimana ditentukan dalam Pasal 5 Undang-Undang Perlindungan Konsumen, yang meliputi:

a. membaca atau mengikuti petunjuk informasi dan prosedur pemakaian atau pemanfaatan barang dan/atau jasa, demi keamanan dan keselamatan;

b. beritikad baik dalam melakukan transaksi pembelian barang dan/atau jasa;

c. membayar sesuai dengan nilai tukar yang disepakati;

d. mengikuti upaya penyelesaian hukum sengketa perlindungan konsumen secara patut.

Menyeimbangi hak yang dimiliki konsumen sebagiamana diatur dalam UndangUndang Perlindungan Konsumen, maka Pasal 6 menentukan pula hak yang dimiliki oleh pelaku usaha, meliputi:

a. hak untuk menerima pembayaran yang sesuai dengan kesepakatan mengenai kondisi dan nilai tukar barang dan/atau jasa yang diperdagangkan;

b. hak untuk mendapat perlindungan hukum dari tindakan konsumen yang beritikad tidak baik;

c. hak untuk melakukan pembelaan diri sepatutnya di dalam penyelesaian hukum sengketa konsumen;

d. hak untuk rehabilitasi nama baik apabila terbukti secara hukum bahwa kerugian konsumen tidak diakibatkan oleh barang dan/atau jasa yang diperdagangkan;

e. hak-hak yang diatur dalam ketentuan peraturan perundang-undangan lainnya.

Sebagai bentuk konsistensi dan konsekuensi hukum ditentukannya hak konsumen secara normatif, maka diatur pula kewajiban pelaku usaha meliputi:

a. beritikad baik dalam melakukan kegiatan usahanya;

b. memberikan informasi yang benar, jelas dan jujur mengenai kondisi dan jaminan barang dan/atau jasa serta memberi penjelasan pcnggunaan, perbaikan dan pemeliharaan;

c. memperlakukan atau melayani konsumen secara benar dan jujur serta tidak diskriminatif;

d. menjamin mutu barang dan/atau jasa yang diproduksi dan/atau diperdagangkan berdasarkan ketentuan standar mutu barang dan/atau jasa yang berlaku; 
e. memberi kesempatan kepada konsumen untuk menguji, dan/atau mencoba barang dan/atau jasa tertentu serta memberi jaminan dan/atau garansi atas barang yang dibuat dan/atau yang diperdagangkan;

f. memberi kompensasi, ganti rugi dan/atau penggantian atas kerugian akibat penggunaan, pemakaian dan pemanfaatan barang dan/atau jasa yang diperdagangkan;

g. memberi kompensasi, ganti rugi dan/atau penggantian apabila barang dan/atau jasa yang diterima atau dimanfaatkan tidak sesuai dengan perjanjian.

Secara eksplisit, keberadaan Pasal 7 Undang-Undang Perlindungan Konsumen lebih menekankan pada pelaku usaha dalam menjalankan usahanya untuk menerapkan prinsip itikad baik. Hal ini disebabkan kemungkinan terjadinya kerugian bagi konsumen dimulai sejak produk dirancang atau diproduksi oleh pelaku usaha (Aulia Muthiah, 2018). Sehingga diharapkan dengan mengedepankan kegiatan usaha yang menjalankan itikad baik dan mempertimbangkan segala aspek yang baik bagi konsumen, maka dapat menghindari kerugian yang akan diterima konsumen dikemudian hari. Asas itikad baik ini sebenarnya telah lama dikenal dalam hukum perdata yang menjadi dasar perjanjian dalam hukum perlindungan kosumen.

Berkaitan dengan kasus penggunaan klorin sebagai BTP dalam produk mie soun, maka perbuatan pelaku usaha memang memiliki akibat langsung bagi kesehatan konsumen. Hal ini dikarenakan kandungan klorin yang tidak termasuk dalam kategori BTP yang diperkenankan sebagaimana ditentukan dalam Permenkes Bahan Tambahan Pangan mengindikasikan bahwa klorin tidak direkomendasikan sebagai bahan tambahan yang aman dalam pengolahan pangan. Sehingga, apabila pelaku usaha tetap mengabaikan hal tersebut maka pelaku usaha bertanggung jawab atas cacat yang terkandung dalam produknya.

Perlindungan hukum yang ditentukan dalam Undang-Undang Perlindungan Konsumen terhadap produk pangan adalah tanggung jawab pelaku usaha atas kerugian sebagai akibat yang ditimbulkan oleh produk tersebut. Hal ini lazim disebut tanggung jawab mutlak (strict liability). Dalam hal ini konsumen berhak mendapatkan ganti rugi atau kompensasi terhadap kerugian yang dideritanya. Tanggung jawab mutlak (strict liability) lebih berfokus pada kondisi produk, bukan pada perilaku konsumen. Prinsip tanggung jawab mutlak diklasifikasikan ke dalam halhal yang berkaitan dengan hal berikut ini (Adrian Sutedi, 2008):

a. Proses produksi, yaitu yang menyangkut tanggung jawab produsen atas produk yang dihasilkannya bila menimbulkan kerugian bagi konsumen. Misalnya antara lain menyangkut tanggung jawab atas kualitas produk, tanggung jawab atas produk yang cacat, baik cacat desain maupun cacat produk, dan sebagainya.

b. Promosi niaga/iklan, yaitu yang menyangkut tanggung jawab produsen atas promosi niaga/iklan tentang hal ihwal produk yang dipasarkan bila menimbulkan kerugian bagi konsumen.

c. Praktik perdagangan yang tidak jujur, seperti persaingan curang, pemalsuan, penipuan, dan periklanan menyesatkan.

Dalam hal ini penyertaan senyawa klorin sebagai bahan tambahan dalam produk mi soun jelas memenuhi unsur yang tertera pada huruf a. Karena dalam proses produksi mengabaikan kualitas produk dan keberadaan produk itu berdampak bagi kesehatan konsumen. Meskipun dampaknya baru dapat terlihat setelah pemakaian dalam jangka waktu yang panjang, telah dijelaskan sebelumnya bahwa klorin sebagai senyawa kimiawi berbahaya bagi kesehatan tubuh bila dikonsumsi. Tanggung jawab ini melekat pada pelaku usaha dikarenakan sejak awal pembuatan produk mi soun pelaku usaha sudah lalai dan sengaja menggunakan senyawa klorin sebagi BTP dalam produknya. Padahal, seharusnya pelaku usaha yang beritikad baik dapat mencari informasi atau dapat melakukan pengujian laboratorium terlebih dahulu terhadap BTP yang akan digunakan. 
Jurnal Yustika

Vol. 21 No. 2, Des 2018

Halaman I 39

Kedudukan Pelaku Usaha dan

Konsumen dalam

Hukum

Perlindungan

Konsumen

Heru S. Lumban Gaol

Fransisca Y. Prawitasari

\subsection{Kesadaran Konsumen dan Hukum Perlindungan Konsumen sebagai Hukum Progresif}

Hadirnya Undang-Undang Perlindungan Konsumen seyogyanya merupakan sandaran hukum bagi konsumen dalam rangka memperjuangkan hak-haknya sebagai pengguna barang/jasa. Lahirnya Undang-Undang Perlindungan Konsumen juga sebagai suatu konsekuensi Indonesia sebagai Negara hukum, dimana hukum menjadi tonggak dasar dalam mencapai tujuan hukum yaitu keadilan, kepastian, dan kemanfaatan. Persoalannya dalam pembentukan hukum itu sendiri tidak hanya berdiri atas landasan yuridis dan filososfis semata, akan tetapi berkaitan juga dengan landasan sosiologis (Firman Tumantara Endipradja, 2016). Keberadaan landasan sosiologis berperan penting dalam perwujudan hukum yang bersifat progresif, karena hukum sesungguhnya membutuhkan kesadaran masyarakat dan keyakinan masyarakat untuk menerima dan mengimplementasikan hukum itu dalam kehidupan seharihari, tidak semata-mata penjelmaan kata-kata dalam perwujudan pasal semata.

Landasan sosiologi sebagai pembentukan hukum yang bersifat progresif sendiri dapat dilihat dari konsep atau pemahaman bahwa hukum adalah untuk manusia, bukan manusia untuk hukum (Satijpto Rahardjo, 2004). Dengan demikian, manusia tidak harus selalu diupayakan atau tidak dipaksakan untuk masuk dan tunduk pada hukum melainkan sebaliknya. Konsepsi hukum progresif dalam hukum perlindungan konsumen mengajak para pihak yang saling memiliki hubungan hukum untuk secara sukarela sadar akan keberadaan hukum itu sebagai upaya mencapai keadilan, kepastian dan kemanfaatan hukum. Sehingga hukum menjadi sarana bukan alat.

Berkaitan dengan hal tersebut, hubungan hukum antara pelaku usaha dan konsumen sudah dimulai sejak awal proses produksi, distribusi, pemasaran, hingga penawaran. Hubungan ini juga telah mengalami perubahan konstruksi hukum, yang awalnya dibangun dengan prinsip caveat emptor menjadi caveat venditor (Zulham, 2013). Prinsip caveat venditor mendudukan peran pelaku usaha untuk berhati-hati dalam hubungan hukum tersebut, sejak proses produksi hingga penawaran barang/jasa. Keberadaan prinsip ini sekaligus mendudukan kedudukan pelaku usaha sebagai pelaku utama dalam Hukum Perlindungan Konsumen. Prinsip caeveat venditor ini juga sejalan dengan penerapan prinsip tanggung jawab mutlak (strict liability) yang didasarkan pada alasan konsumen tidak dapat berbuat banyak untuk memproteksi diri dari resiko kerugian yang disebabkan oleh produk yang cacat. Pelaksanaan prinsip caveat venditor juga sebagai bentuk kesadaran dari pelaku usaha dalam menjalankan usaha dengan itikad baik sebagai kewajibannya, dimulai dari proses produksi hingga penawaran.

Sejatinya, Undang-Undang Hukum Perlindungan Konsumen memang lebih banyak mengatur mengenai perilaku pelaku usaha (Firman Tumantara Endipradja, 2016). Dengan demikian, konstruksi hukumnya tidak dapat dikatakan sepenuhnya sebagai hukum yang progresif. Penekanan tanggung jawab yang hanya berpaku pada tanggung jawab mutlak (srtict liability) pelaku usaha semata terhadap kecacatan dalam produk adalah pembiaran bagi konsumen untuk melupakan kewajibannya dan menjadi konsumen tidak mandiri. Padahal dalam Pasal 3 huruf a Undang-Undang Perlindungan Konsumen ditentukan "perlindungan konsumen bertujuan meningkatkan kesadaran, kemampuan, dan kemandirian konsumen untuk melindungi diri". Pertimbangan atas aspek perilaku konsumen itu sendiri juga penting, apakah konsumen itu aktif atau pun pasif. Perlu dicermati lebih lanjut, bahwa Undang-Undang Perlindungan Konsumen juga menentukan kewajiban konsumen yang berjalan beriringan dengan haknya. Salah satu kewajiban itu ditentukan dalam Pasal 5 huruf a yaitu "kewajiban konsumen untuk membaca atau mengikuti petunjuk informasi dan prosedur pemakaian atau pemanfaatan barang dan/atau jasa, demi keamanan dan keselamatan". Pasal 5 huruf a ini sekaligus mereduksi prinsip tanggung jawab mutlak (strict liability) yang melekat pada pelaku usaha. 
Ditentukan dalam Pasal 27 Undang-Undang Perlindungan Konsumen bahwa Pelaku usaha yang memproduksi barang dibebaskan dari tanggung jawab atas kerugian yang diderita konsumen, apabila:

a. barang tersebut terbukti seharusnya tidak diedarkan atau tidak dimaksudkan untuk diedarkan;

b. cacat barang timbul pada kemudian hari;

c. cacat timbul akibat ditaatinya ketentuan mengenai kualifikasi barang;

d. kelalaian yang diakibatkan oleh konsumen;

e. lewatnya jangka waktu penuntutan 4 (empat) tahun sejak barang dibeli atau lewatnya jangka waktu yang diperjanjikan.

Apabila ketentuan ini dicermati secara seksama oleh konsumen, maka perilaku konsumen yang lalai dalam menjalankan kewajibannya sebagaimana ditentukan dalam Pasal 5 huruf a dapat menyebabkan tanggung jawab pelaku usaha gugur. Ketentuan dalam Pasal 27 huruf e UndangUndang Perlindungan Konsumen disatu sisi juga menimbulkan konstradiksi dan ketidakpastian, khususnya terkait jangka waktu penuntutan ganti rugi dan kemungkinan untuk adanya penuntutan pidana. Hal ini dikarenakan lewatnya jangka waktu penuntutan dihitung empat tahun sejak barang dibeli atau lewatnya jangka waktu yang diperjanjikan, sementara efek yang ditimbulkan dari BTP yang mengandung unsur klorin tidak selalu berdampak seketika bagi kesehatan.

Problematika sebagaimana diuraikan sebelumnya tentu memerlukan peran serta konsumen untuk menjadi konsumen yang mandiri, cerdas, dan aktif. Artinya, pertama-tama konsumen diharapkan menyadari keberadaan hak dan kewajibannya sebagai insan hukum dan menyadari kepentingannya untuk memperoleh hidup yang sehat. Terkait BTP klorin dalam kasus mi soun, seharusnya konsumen dapat membaca informasi pada label produk mengenai kandungan BTP dalam produk mi soun. Apabila tidak tertera label yang menjelaskan kandungan pada produk, seharusnya konsumen dapat mawas diri atau dapat menanyakan informasi mengenai proses pengolahan produk mi soun kepada penjual. Selanjutnya, dengan berbekal informasi yang jelas dan cukup, konsumen dapat melakukan pilihan pada produk yang akan dikonsumsinya. Hal ini tentu sejalan dengan hak yang dimiliki oleh konsumen untuk memperoleh informasi yang benar, jelas, dan jujur mengenai kondisi barang/jasa yang diproduksi.

Pemahaman konsep hukum progresif seperti harus menjadi kiblat baru bagi konsumen di Indonesia. Mengingat Indonesia merupakan negara berkembang yang iklim usahanya belum dapat sepenuhnya diatur secara ketat oleh pemerintah, terutama untuk sektor UMKM yang ada di beberapa daerah. Beberapa upaya baik itu sosialisasi dan penerapan standardisasi produk juga terus diupayakan pemerintah, namun masih belum cukup efektif mengingat pasar dari pelaku usaha adalah konsumen itu sendiri. Dengan adanya sikap konsumen yang mandiri, cerdas, dan aktif akan menumbuhkan iklim baru dalam hukum perlindungan konsumen. Nantinya, hukum perlindungan konsumen tidak semata-mata bersifat positivistik sebagai ketentuan yang mengatur perilaku konsumen, akan tetapi dapat menjadi hukum progresif yang mampu meningkatkan kesadaran konsumen agar paham akan hak dan kewajibannya. Sebab, tidak dapat dipungkiri dalam konsep pasar itu sendiri sesuatu tidak akan ada apabila tidak ada permintaan. Sebaliknya, penawaran ada karena adanya permintaan.

\section{Kesimpulan}

Kedududukan pelaku usaha dan konsumen dalam era globalisasi dan perkembangan hukum progresif seharusnya mendudukan keduanya dalam tatanan yang seimbang. Meskipun diakui bahwa dalam hubungan hukum yang terlihat horizontal itu masih memungkinkan terjadi 
Jurnal Yustika

Vol. 21 No. 2, Des 2018

Halaman | 41

Kedudukan Pelaku

Usaha dan

Konsumen dalam

Hukum

Perlindungan

Konsumen

Heru S. Lumban Gaol

Fransisca Y. Prawitasari

eksploitasi oleh salah satu pihak. Namun, sebenarnya keberadaan Undang-Undang Perlindungan Konsumen telah mewadahi pelaku usaha dan konsumen untuk dapat berada dalam posisi yang seimbang. Hal ini dapat dilihat dari penjabaran Bab III Pasal 4-7 yang menentukan hak dan kewajiban konsumen dan pelaku usaha. Persoalannya adalah kesadaran dan perhatian konsumen dan pelaku usaha dalam pengolahan pangan yang berkualitas, aman, dan bergizi masih dapat dikatakan sangat minim. Pada dasarnya, hal ini akan kembali merugikan konsumen dan menempatkan konsumen pada posisi yang lemah sekalipun dilindungi oleh Undang-Undang Perlindungan Konsumen. Padahal dengan perkembangan hukum positif, konsumen memiliki peran yang utama dalam memahami hak dan kewajibannya sebagai pengguna barang/jasa.

Berkaitan dengan kasus penggunaan BTP Klorin dalam produk mie soun, meski Lampiran I Peraturan Menteri Kesehatan Nomor 033 Tahun 2012 tentang BTP tidak mengategorikan klorin sebagai kategori BTP yang diizinkan dan Lampiran II Peraturan Menteri Kesehatan Nomor 033 Tahun 2012 tentang BTP tidak melarang klorin dalam BTP secara implisit, namun tidak menjadi alasan bagi konsumen untuk tidak berupaya mencari informasi terkait kejelasan menegnai BTP yang mengandung klorin. Terlebih, isu mengkonsumsi makanan dengan kadar klorin dapat berdampak pada kesehatan telah menjadi isu lama.

Pergeseran prinsip let buyer be aware (caveat emptor) menjadi prinsip let seller be aware (caveat venditor) seharusnya tidak ditempatkan sebagai pedoman mutlak untuk menentukan siapa yang bertanggung jawab dan tidak bertanggung jawab. Sudah selayaknya baik itu konsumen dan pelaku usaha sama-sama mengedepankan kehati-hatiannya dan memperhatikan perilakunya masing-masing. Hal ini sekaligus sebagai perwujudan prinsip itikad baik dalam hubungan hukum perlindungan konsumen. Pelaksanaan prinsip itikad baik merupakan penjelmaan dari keseimbangan kedudukan antara pelaku usaha dan konsumen sebagai subyek hukum. Bagi pelaku usaha itikad baik dapat diwujudkan melalui upaya menjaga kualitas produk yang dihasilkan. Sedangkan, prinsip itikad baik dapat dilakukan konsumen dengan berupaya mencari informasi terkait produk yang akan dikonsumsi. Pada akhirnya berdasarkan informasi yang konsumen peroleh, konsumen dapat menentukan pilihannya pada barang/jasa yang ada. 


\section{Daftar Referensi}

Buku:

Adiwisastra, A. (1987). Keracunan (Sumber, Bahaya, serta Penanggulangannya), Bandung: Angkasa. Endipradja, Firman Tumantara. (2016) Hukum Perlindungan Konsumen (Filosofi Perlindungan Konsumen dalam Perspektif Politik Hukum Negara Kesejahteraan). Malang: Setara Press, Malang, 2016

Khomsan, Ali. (2006). Solusi Makanan Sehat. Jakarta: PT. Raja Grafindo Persada

Mutiah, Aulia. (2018). Hukum Perlindungan Konsumen (Dimensi Hukum Positif dan Ekonomi Syariah). Yogyakarta: Pustaka Baru Press

Rahardjo, Satijpto. (2014). Ilmu Hukum Pencarian, Pembebasan, dan Pencerahan. Surakarta: Universitas Muhammadiyah.

Samsul, Inosentius. (2004). Perlindungan Konsumen, Kemungkinan Penerapan Tanggung Jawab Mutlak. Jakarta: Universitas Indonesia.

Sutedi, Adrian. (2008). Tanggung Jawab Produk Dalam Hukum Perlindungan Konsumen. Bogor: Ghalia Indonesia.

Wulandari, Andi Sri Rezky \& Nurdiyana Tadjuddin. (2018). Hukum Perlindungan Konsumen. Mitra Wacana Media: Jakarta.

Yuliarti, N. (2007). Awas, Bahaya Di Balik Lezatnya Makanan. Yogyakrta: Andi

Zulham. (2013). Hukum Perlindungan Konsumen. Kencana Prenada Media Group: Jakarta.

Skripsi/Disertasi/Tesis:

Al-Shirrazy, Usay. (2014). Konsep dan Praktek Nutrifikasi Pangan. UPN Veteran, Jakarta .

Belia, Bunga Septiani. (2015). Strategi Pebolahan Limbah Industri Mi Sound an Dampaknya Terhadap Masyarakat Sekitar (Studi Kasus Desa Majung, Kecamatan Ngawen, Kabupaten Klaten). Universitas Diponegoro, Semarang.

Prawitasari, Fransisca Yanita. (2013). Tanggung Gugat Pelaku Usaha Atas Pembuatan Produk Mi Soun Dengan Menggunakan Bahan Kimia Kaporit Berlebih. Universitas Surabaya, Surabaya.

Artikel Jurnal:

Hernawati, Elly. (2017). Prinsip Kehati-hatian Sebagai Bentuk Perlindungan Hukum Terhadap Hak Kesehatan Konsumen Atas Penggunaan Bahan Tambahan Pangan. Jurnal Magister Hukum"Argumentum", Fakultas Hukum Universitas Surabaya, 3(1), 543-565.

Rosita, Dewi, dkk. (2016). Analisis Kandungan Klorin Pada Beras yang Beredar Di Pasar Besar Kota Malang Sebagai Sumber Belajar Biologi. Jurnal Pendidikan Biologi Indonesia, 2(1), 88-93.

Artikel Surat Kabar:

Wijaya, C. Hanny. (2007, 16 Januari). Klorin versus Pangan. hlm.8-9.

Website:

Adi, Ais. (2012). Waspada Mi Berbumbu Kaporit. Diambil dari situs http:// news.liputan6.com/read/432198/waspada-mi-berbumbu-kaporit
Jurnal Yustika Vol. XX No. X, Des 201X

Halaman | 42

Kedudukan Pelaku Usaha dan

Konsumen dalam Hukum

Perlindungan Konsumen

Heru S. Lumban Gaol Fransisca Y. Prawitasari 
Jurnal Yustika

Vol. 21 No. 2, Des 2018

Halaman | 43

Kedudukan Pelaku

Usaha dan

Konsumen dalam

Hukum

Perlindungan

Konsumen

Heru S. Lumban Gaol

Fransisca Y. Prawitasari
Anonim. (7 Juni 2017). Polisi Gebrek Pabrik Sohun Berkaporit di Jember. Diambil dari situs http://news.liputan6.com/read/2981211/polisi-gerebek-pabrik-sohun-berkaporit-diJember

Anonim. (Juli 2017). Polda Jambi Gerebek pabrik Mi Berbahan Kimia. Diambil dari situs http://jambi.antaranews.com

Anonim. (2019).Tanggung Jawab. Diambil dari situs https:// kbbi.web.id.

Perturan Perundang-Undangan:

Undang-Undang Nomor 8 Tahun 1999 tentang Perlindungan Konsumen

Undang-Undang Nomor 18 Tahun 2012 tentang Pangan

Peraturan Menteri Kesehatan Republic Indonesia Nomoe 033 Tahun 2012 tentang bahan Tambahan Pangan 